\title{
PLANKTON INVESTIGATION IN INLET WATERS ALONG THE COAST OF JAPAN. -III. THE PLANKTON OF IMARI BAY IN KYUSYU-
}

\author{
$\operatorname{AUTHOR}(\mathrm{S}):$ \\ Yamazi, Isamu
}

\section{CITATION:}

Yamazi, Isamu. PLANKTON INVESTIGATION IN INLET WATERS ALONG THE COAST OF JAPAN. - III. THE PLANKTON OF IMARI BAY IN KYUSYU-. PUBLICATIONS OF THE SETO MARINE BIOLOGICAL LABORATORY 1952, 2(2): 289-304

ISSUE DATE:

1952-10-05

URL:

http://hdl.handle.net/2433/174674

RIGHT: 


\title{
PLANKTON INVESTIGATION IN INLET WATERS ALONG THE COAST OF JAPAN
}

\author{
III. THE PLANKTON OF IMARI BAY IN KYUSYU* \\ ISAMU YAMAZI \\ Seto Marine Biological Laboratory, Sirahama
}

\section{With 8 Text-figures}

With a purpose to compare the planktonic and benthic communities of Imari Bay on the northern coast of Kyusyu with those of Nagasaki Bay on the western coast in relation to the topographical and hydrological conditions, I, conjointly with Mr. T. HABE and H. HukUdA, made a surveying trip to these bays during the early summer of 1949 . The present paper deals with the planktological data obtained by the survey made in Imari Bay on July 12-13. The methods of survey and examining the material are similar to those used in Akkeshi Bay and the other inlets along the coast of Hokkaido (YAMAZI, 1950; 1951). The plankton samples were vertically collected from bottom to the surface by a KitAHARA's quantitative silk tow net in a small scale. The diameters of the mouth and largest part of the net are $11.25 \mathrm{~cm}$ and $25 \mathrm{~cm}$ respectively and the length is about $50 \mathrm{~cm}$. So a measured quantity of water passing through the net is about 10 liters per one meter haul. The mesh of the Müller's gauze is No. XX-13. The rough volume of every material was measured with a measuring tube by the settling method with 24 hours.

During the field work I was helped by Mr. T. HABE and H. Hukuda of the Kyoto University and gentlemen of the Hatatu Fishing Guild. To all these gentlemen I wish to express my hearty thanks. My thanks are also due to Prof. D. Mryadi, Dr. H. UTiNomi and Dr. T. Tokioka for many valuable suggestions received in preparing papers of this series.

\section{Hydrological Conditions}

Imari Bay (Fig. 1) faces the Iki Strait and lies on the northwestern coast of Kyusyu Island. It is bounded northwestwards by the cape Tusaki and

* Contributions from the Seto Marine Biological Laboratory, No. 187.

Publ. Seto Mar. Biol. Lab., II (2) 1952. (Article 17) 


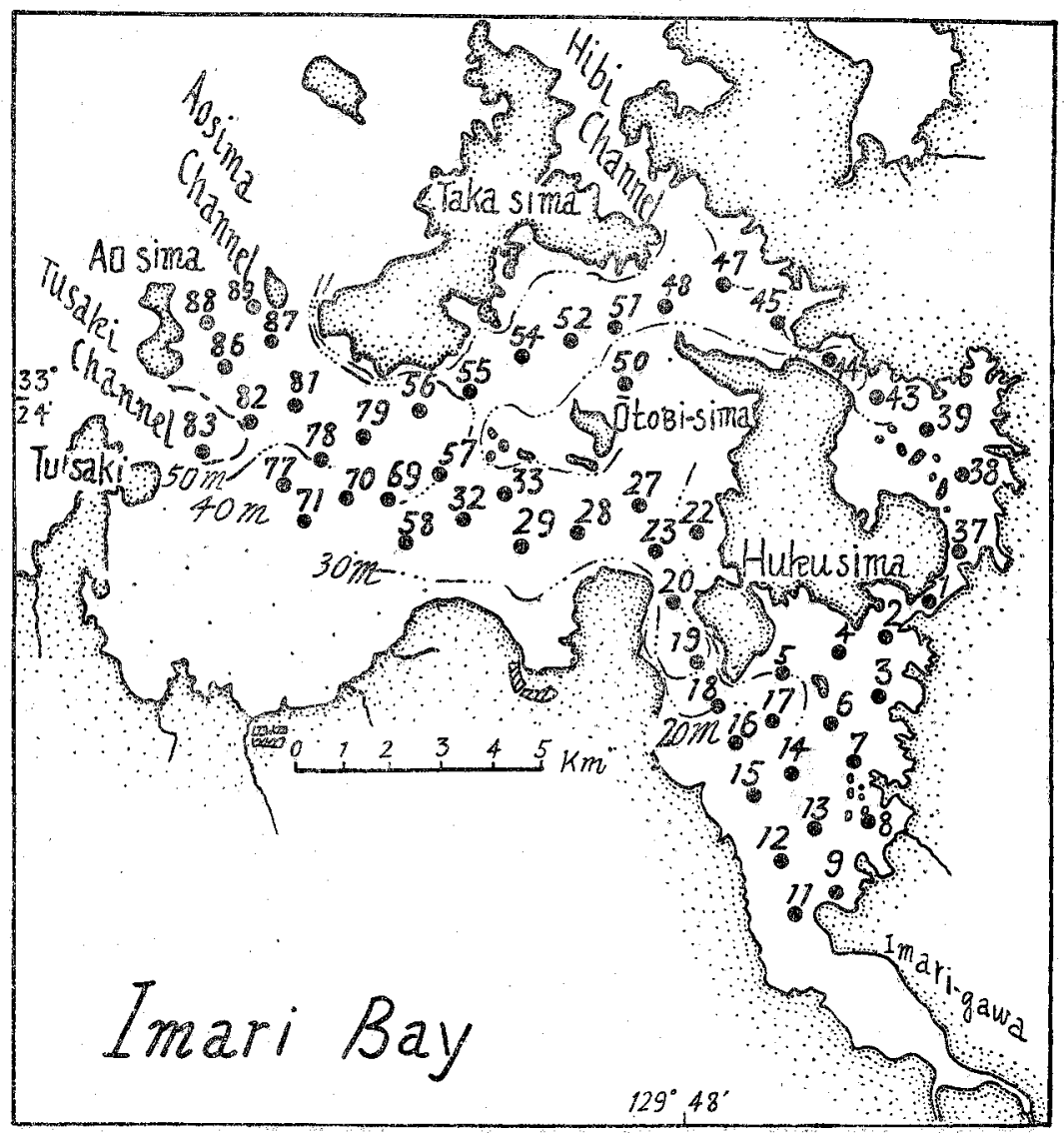

Fig. 1. Map of Imari Bay showing stations and isobaths.

northwards by several islets-Aosima, Izusima, Okonosima, Kurosima and a large island Takasima, and is connected with the Iki Strait by three narrow channels-Tusaki, Aosima and Hibi-suido which are on an average $40-50 \mathrm{~m}$ in depth. In the central part of the bay, there is a large island, Hukusima, which divides the bay into three regions-eastern, western and southern areas.

For convenience sake, I henceforth divide the bay into the inner and outer regions to compare the regional peculiarities, Hukusima lying on the boundary between them; thus the western area of the bay belongs to the outer region, and the eastern and southern areas to the inner region.

The only important river, Imari-gawa pours into the inner region of the bay from the south. The southern part of the inner region is relatively shallow, measuring about $6-18 \mathrm{~m}$ in depth. The central part of the outer region is 
deeper and has the depth of about $30-40 \mathrm{~m}$. The depth of more than $40-50 \mathrm{~m}$ is measured near the northwestern entrance of the bay.

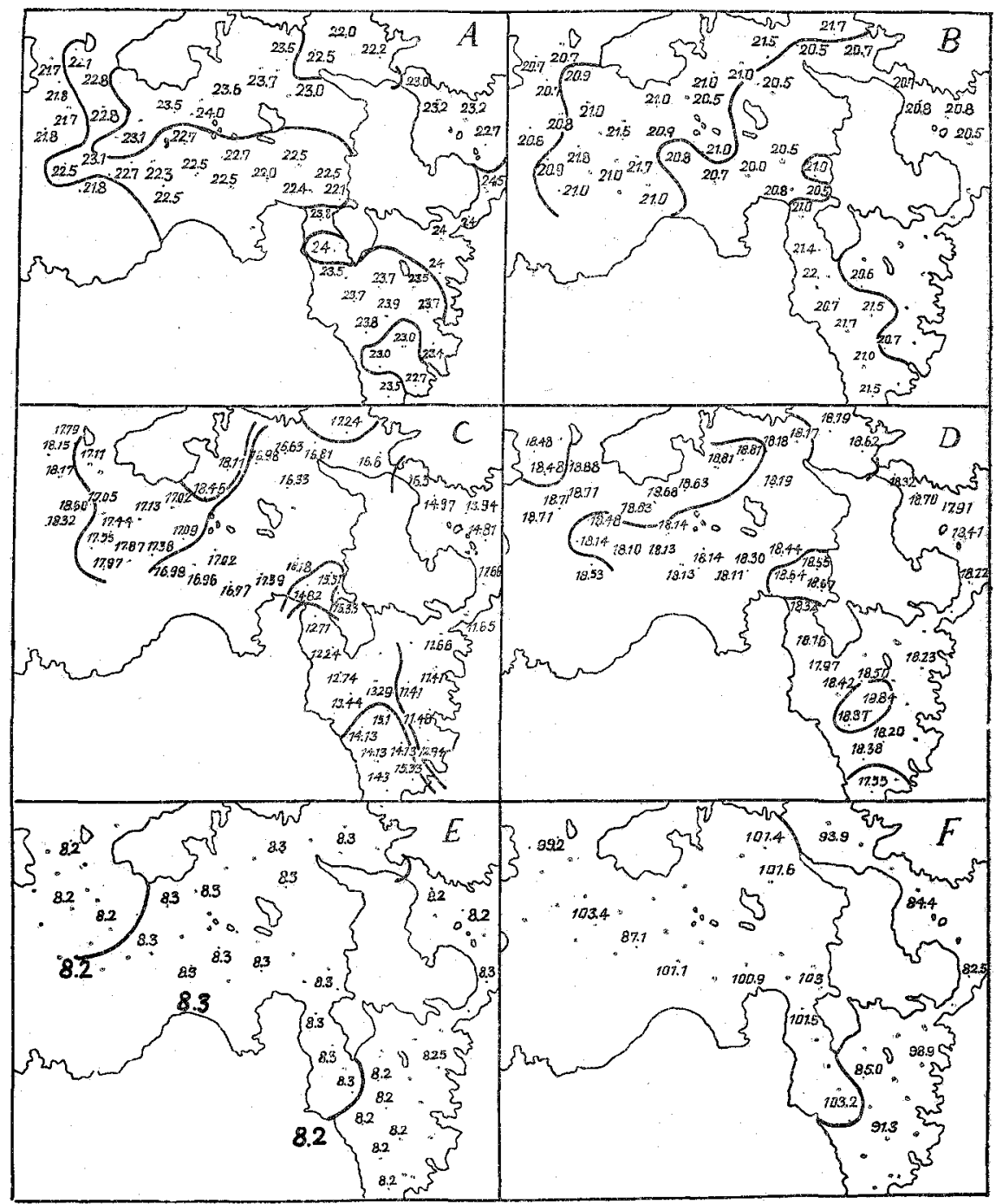

Fig. 2. Hydrological conditions during the survey (July 12-13, 1949). I.

A. Distribution of water temperature $\left({ }^{\circ} \mathrm{C}\right)$ of the superficial layer.

B. Water temperature $\left({ }^{\circ} \mathrm{C}\right)$ of the $5 \mathrm{~m}$ layer.

C. Chlorinity $(\mathrm{Cl} \%)$ of the superficial layer.

D. Chlorinity $(\mathrm{Cl} \%$ ) of the $5 \mathrm{~m}$ layer

E. $\mathrm{pH}$ value of the $5 \mathrm{~m}$ layer.

F. Saturation degree of oxygen of the $5 \mathrm{~m}$ layer.

Water temperature (Fig. 2, A and B): The surface water temperature 
ranged from $21.7^{\circ} \mathrm{C}$ to $24.5^{\circ} \mathrm{C}$, being lower near the mouth of the bay than at the inner region $\left(23-24^{\circ} \mathrm{C}\right)$. In the central part of the outer region it was a

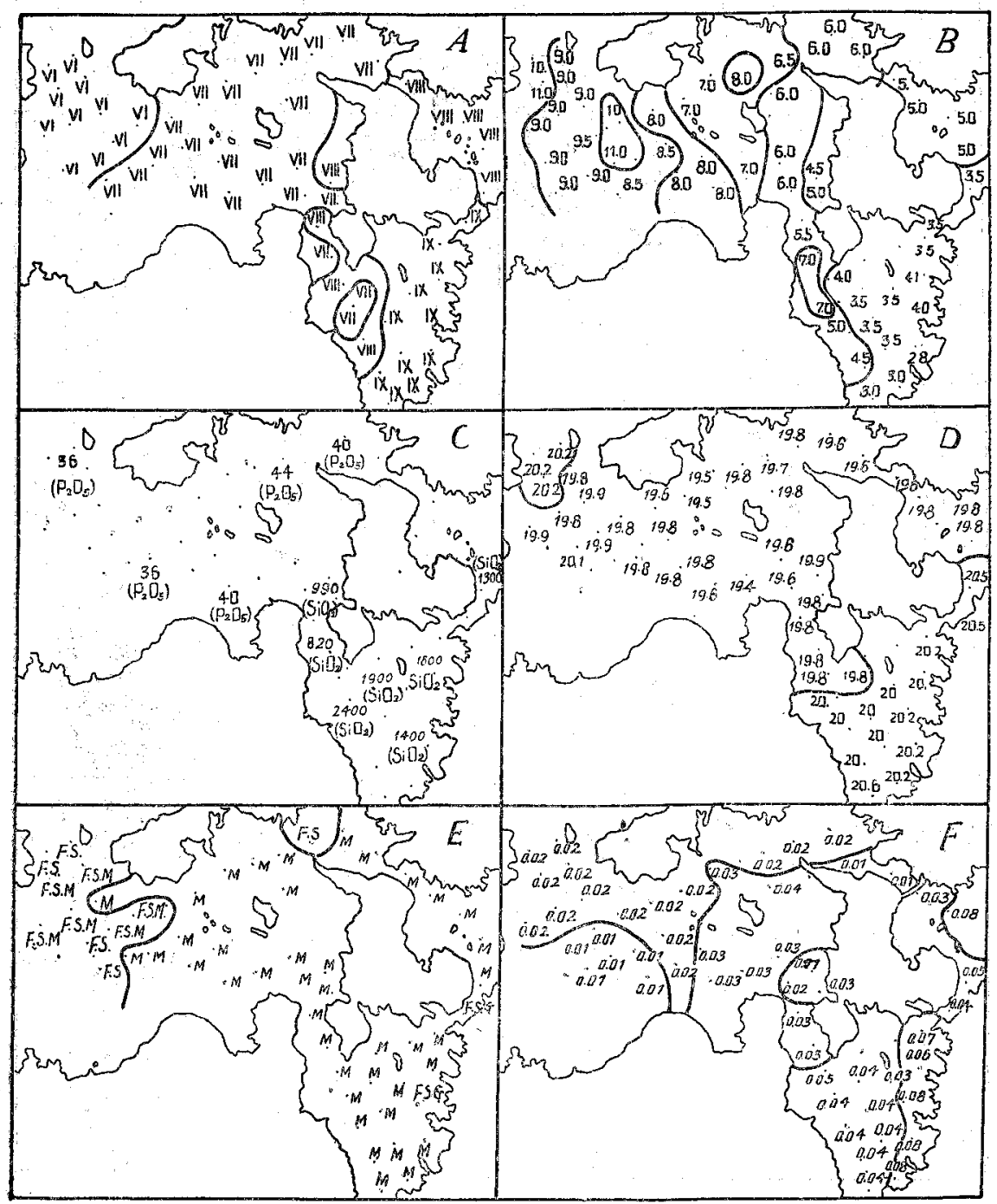

Fig. 3. Hydrological conditions during the survey (July 12-13, 1949). II.

A. Distribution of water color.

B. Distribution of transparency.

C. Distribution of phosphates $\left(\mathrm{P}_{2} \mathrm{O}_{5} \mathrm{mg} / \mathrm{m}^{3}\right)$ and silicates $\left(\mathrm{SiO}_{2} \mathrm{mg} / \mathrm{m}^{3}\right)$ of the $5 \mathrm{~m}$ layer.

D. Distribution of mud temperature $\left({ }^{\circ} \mathrm{C}\right)$

E. Texture of ground.

F. Settling volume $(c c)$ of plankton per 10 liters between surface and bottom. 
little higher in the north $\left(21.7-22.8^{\circ} \mathrm{C}\right)$ than in the south $\left(22-22.7^{\circ} \mathrm{C}\right)$, and in the mouth it was higher in the west than in the east. The water temperature of the $5 \mathrm{~m}$ layer was lower than that of the surface (about $1-3^{\circ} \mathrm{C}$ ), and was lower both in the mouth and northwestern part of the outer region than in the inner region. The temperature at the western half of the outer region was a little higher than at the eastern half.

Chlorinity (Fig. 2, C and D): The chlorinity of the water in the surface layer was above $18 \mathrm{Cl} \%$ near the mouth, about $17 \mathrm{Cl} \%$ in the middle of the outer region, and $11-15 \mathrm{Cl} \%$ in the inner region. The chlorinity of the $5 \mathrm{~m}$ layer was almost uniform (18-18.8 $\mathrm{Cl} \%)$. As shown in Fig. 2, D, the isohaline of $18.5 \mathrm{Cl} \%$ was in the mouth and northern half of the outer region.

Dissolved oxygen content and pH value: As shown in Fig. $2, \mathrm{E}$, the $\mathrm{pH}$ value of the $5 \mathrm{~m}$ layer was comparatively lower, being about 8.2-8.3. The $\mathrm{pH}$ 8.2 was widely observed in the eastern and southern parts of the inner region and the mouth part of the outer region, and pH 8.3 was only in the central area of the outer region. The dissolved oxygen content was smaller in the inner region than in the outer (Fig. 2, F). The saturation degree of oxygen. of the $5 \mathrm{~m}$ layer was very low (87-103\%) than that of Nagasaki Bay (See No. 4 of this series).

Transparency and water color (Fig. 3, A and B): The transparency of the water was comparatively larger in the mouth and central part of the outer region, being about 6-10 $\mathrm{m}$. of SECCHI's disc and the water color was nos. 6-7 of FOREL's scale; the effect of pollution by sewage was hardly recognized. On the other hand, in the inner region the water showed yellowish color and less transparency (nos. 8-9 of ForeL's scale and 3-5 of the SECCHI's disc).

Phosphates $\left(\mathrm{P}_{2} \mathrm{O}_{5}\right)$ and Silicates $\left(\mathrm{SiO}_{2}\right)$ contents: Those of the $5 \mathrm{~m}$ layer are shown in Fig. 3, C. The phosphates value varied between $30-45 \mathrm{mg} / \mathrm{m}^{3}$ in the outer region. The silicates were $800-1400 \mathrm{mg} / \mathrm{m}^{3}$ in the inner region. These substances were richer than in Nagasaki Bay. The mud temperature and texture of bottom are shown in Fig. $3, \mathrm{D}$ and $\mathrm{E}$.

\section{Plankton}

\section{A. Quantitative Analysis of Plankton}

The plankton samples were hauled at 49 stations (Fig. 1). The settling volume was very scarce, being less than $0.08 \mathrm{cc} / 10$ liters (Fig. $3, \mathrm{~F}$ ). It was larger in the inner region (eastern half $0.05-0.08 \mathrm{cc}$ and western half $0.04 \mathrm{cc}$ ) than in the central part of the outer region $(0.02-0.03 \mathrm{cc})$ as well as in the mouth $(0.02 \mathrm{cc})$, and smallest in the southwestern part of the outer region 
(0.01 cc). The settling volume was far less than that of Nagasaki Bay, owing to the scarceness of diatoms.

The total number of plankton was very small throughout all stations. The largest number was about 11 thousands per 10 liters at St. 38 in the eastern part of inner region and the smallest was about 1 thousand per 10 liters at St. 58 in the southern part of the outer region. Among 49 stations, 12 stations had the population larger than 5 thousands, 14 stations $3-5$ thousands and the remaining 23 stations $1-3$ thousands.

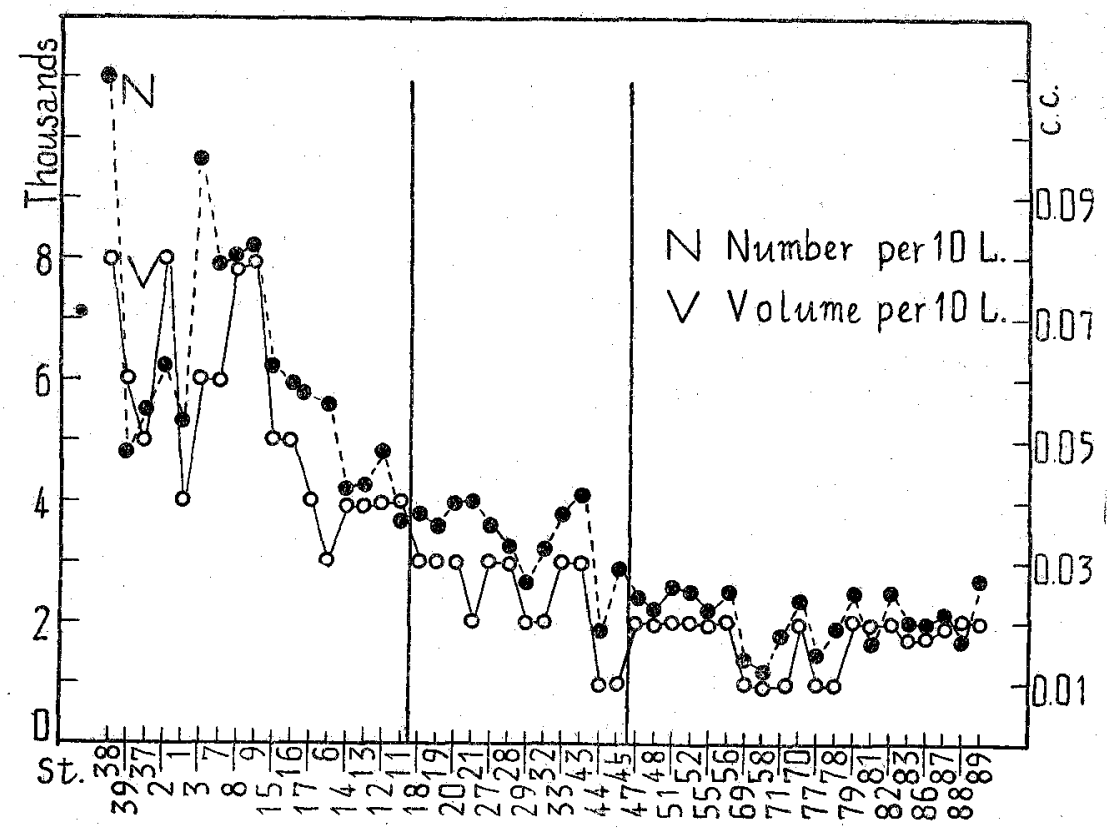

Fig. 4. Relation between the settling volume (cc) of plankton and the number of individuals, cells or colonies (each per 10 liters).

As shown in Fig. 4, the relation between the settling volume and population number per 10 liters was almost the same at all stations. It showed that the composition of population was nearly similar every where, excepting several stations, such as St. 1-3, 7, 37 and 38 , in the eastern part of the inner region, where diatoms were found rather abundantly.

The zooplankton population (Fig. 5, B.) was found densest in the inner region, where the number reached $600-1800$ per 10 liters. It generally decreased towards the eastern and central parts of the outer region (ca. 200-400 individuals) and attained the minimum in the mouth part (less than 200 individuals). The numerical percentage of zooplankton in the total plankton $(Z / \mathrm{N} \times 100)$ (Fig. 5, A) was generally large, 6-10\% in the mouth and 10-14\% in the central 

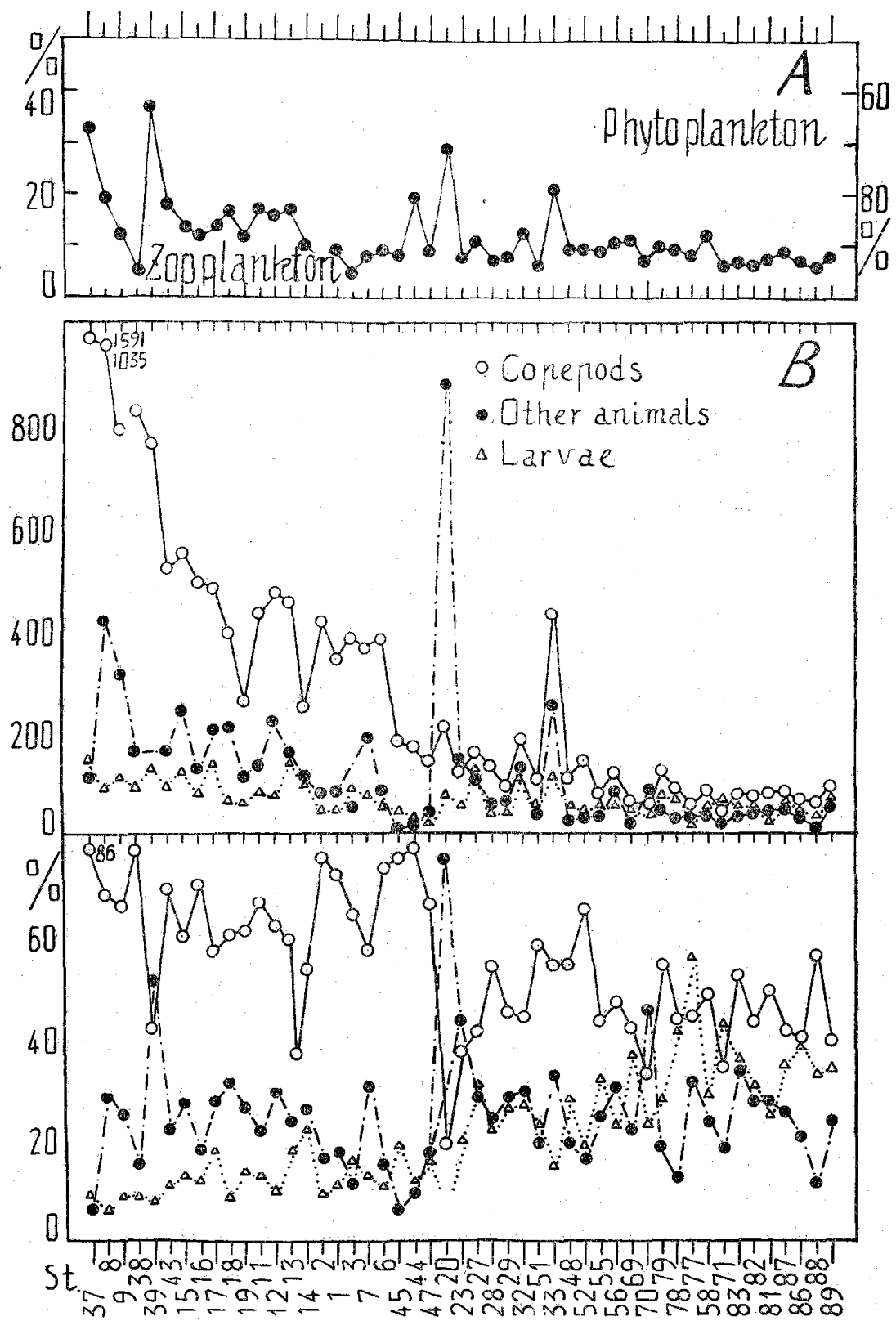

Fig. 5. A. Ratio between zoo- and phytoplankton.

B. Population of zooplankton groups per 10 liters (above) and their percentage composition (below).

part of the outer region and generally increased towards the inner region, up to $20-38 \%$, except at the eastern part. 
The phytoplankton population was very scarce throughout the whole stations. It was fairly richer in the eastern part of the inner region, where 5-9 thousands of cells or colonies per 10 liters were counted. In the other parts they were very poor; that is, in the western half of the southern inner region were counted 3-5 thousands, in the southern half of the outer region 2.5-3 thousands, in the northern half of the outer region 2-2.5 thousands, and in the mouth 1.1-1.9 thousands. The numerical percentage of phytoplankton in the total plankton $(\mathrm{P} / \mathrm{N} \times 100)$ was thus smaller than that of Nagasaki Bay.

\section{B. Qualitative Analysis of Plankton}

Zooplankton: As shown in Fig. 5, B, the main component of zooplankton hauled in the bay was copepod, its percentage being 40-70\%. The other animal groups, such as Protozoa, Copelata, Chaetognatha, Cladocera etc. and various larvae of animals comprising those of molluscs, polychaetes, copepods et al, were only represented by 30-60\% in the total zooplankton. Among the latter, Noctiluca was noticed most abundantly, while the uthers were very sparsely. Of the larval forms, nauplii of copepods and polychaete larvae were the most important components. The veligers of bivalves were comparatively numerous.

The main part of the zoolpankton was occupied by copepods, which were distributed most abundantly in the inner region of the bay. Fig. 6 shows the number and percentage composition of main species of copepods which vary according to places. Of these species, Oithona nana was predominant and at the inner region it was represented by more than $85 \%$ of the total number of copepods. Its percentage was very lower in the central and mouth parts of the outer region, showing $30 \%$ and less than $20 \%$ respectively. Paracalanus parvus, the next important copepod, was evenly distributed in the bay, but its percentage increased gradually towards the central and western parts of the outer region and attained the peak near the mouth (less than $50 \%$ ). Oithona similis was mainly distributed in the outer region of the bay at the frequency of $25 \%$, and in the inner region very sparsely, though with an increasing tendency towards the outer region. Microsetella and Corycaeus were distributed chiefly in the central and mouth parts of the outer region. No oceanic copepod was obtained during this survey.

Noctiluca, which constituted the main part of the other adult plankters, was found richer in the inner region than the outer. Other protozoans were represented by some species of Tintinnoinea, of which Favella campanula, Tintinnus lusus-undae, Tintinnopsis radix, Tinlinnopsis beroidea and Codonollopsis morchella were sparsely found. Copelata were represented by Oikopleura dioica 


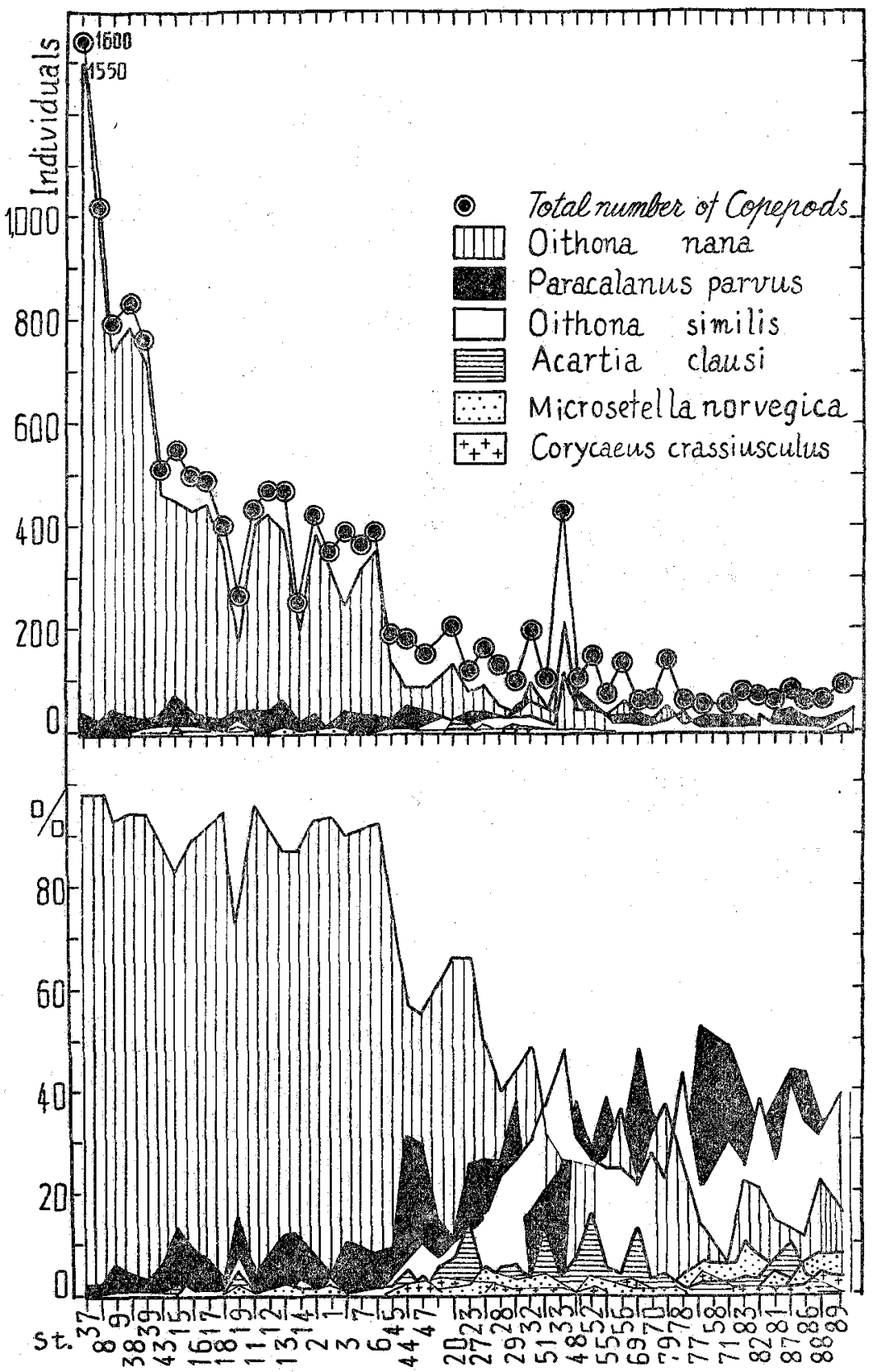

Fig. 6. Number of important copepods per 10 liters between surface and boltom (above) and their percentage composition (below).

which was distributed very sparsely, increasing in number towards the inner region. Other important zooplankters, though very sparse in occurrence, were as follows: 


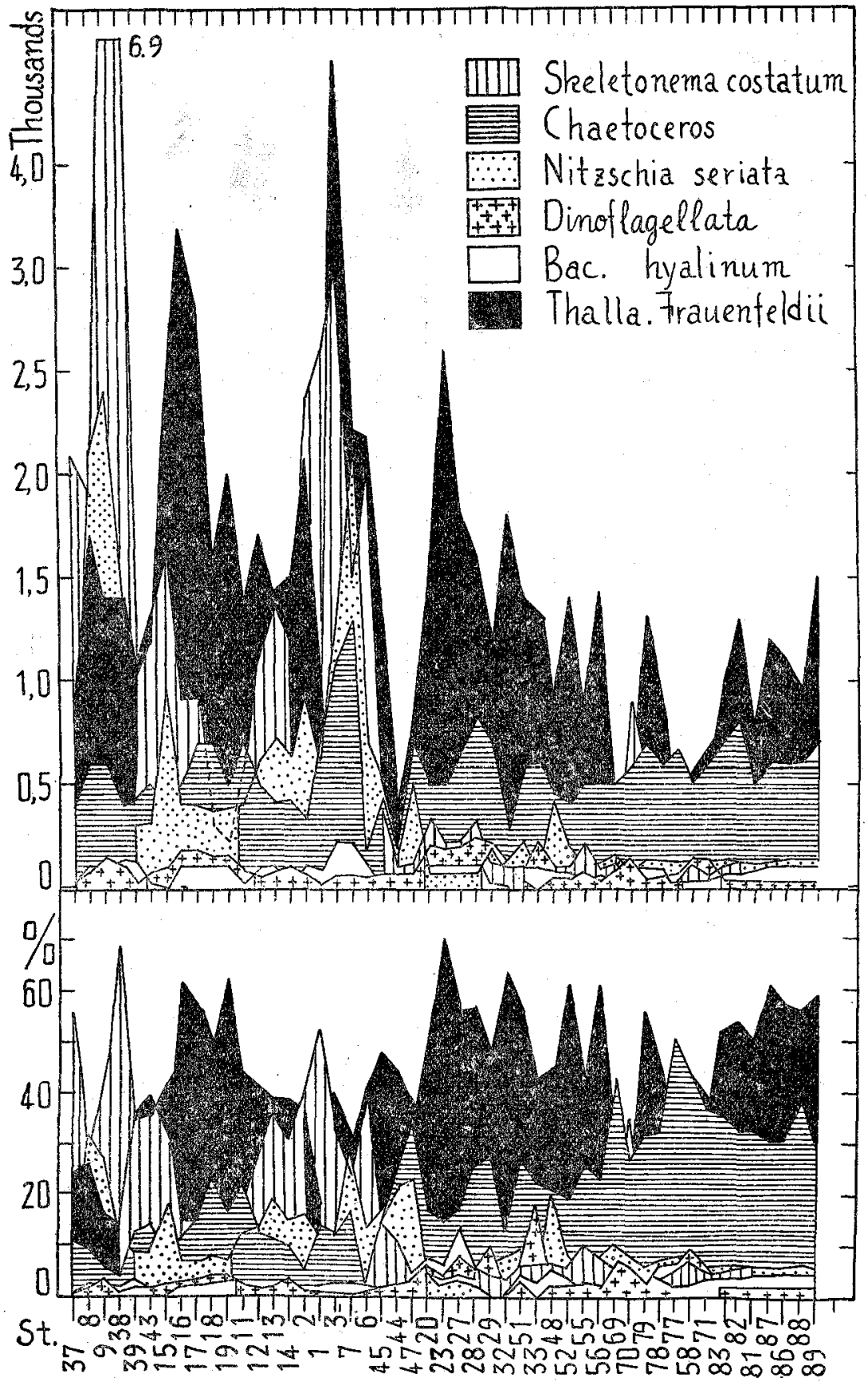

Fig. 7. Cell or colony number of important phytoplankton genera (above and their percentage composition (below). 


\begin{tabular}{c|c|c}
\hline Species & Inner Region & Outer Region \\
\hline Sagitia delicaia & + & + \\
Evadne nordmanni & & + \\
Ponilia schmackeri & + & + \\
\hline
\end{tabular}

The main component of larval plankters was nauplii of copepods, chiefly nauplii and copepodids of Oithona nzma, which richer in the inner region than the outer. Other important nauplii were those of Paracalanus and Acaria. The larvae of bivalves and polychaetes come next in numerical importance and were widely distributed in the bay. The former was found richer in the inner region of the bay, while the latter in the outer region.

Phytoplankton: The main components of phytoplankton are shown in Fig. 7. These composition varied according to stations in the bay, of these Skeletonema costatum was abundant in the inner region, and rapidly decreased. towards the outer region. Nitzschia seriata, another most important one in the inner region, was also distributed very sparsely in the outer region. Thalassiothrix Frauenfeldis was widely distributed, though rather richer in the inner region than in the outer region. Chaetoceros was represented by such species as Ch. didymus, Ch. diadema, Ch. affinis, Ch. Lorenzianus, Ch. laciniosus and Ch. Van Heurcki. Generally speaking, the diatoms were very sparse in the bay, so far as the survey concerned, and some of them showed different tendencies of distribution.

Among dinoflagellates, Ceratium fusus, C. pennatum and C. inflexum occurred in rather large numbers, being richest in the outer region near Hukusima. The first two species were found rather abundantly in the inner region, while the last one in the outer region. The other species, such as C. macroceros, $C$. deflexum and $C$. tripos, were evenly distributed in small numbers. These dinoflagellates may be immigrants from the open sea. The others found during this survey were as follows:

\begin{tabular}{|c|c|c|c|c|}
\hline & \multirow{2}{*}{ Species } & \multirow{2}{*}{ Inner region } & \multicolumn{2}{|c|}{ Outer region } \\
\hline & & & eastern & western \\
\hline \multicolumn{5}{|l|}{ Diatoms } \\
\hline Chaetoceros $d$ & denticulatum & & & + \\
\hline Ch. & pзruvianus & & + & \\
\hline$C h$ & decipiens & + & + & + \\
\hline Ch. & compressus & + & + & + \\
\hline$C h$. & curvisetus & + & + & + \\
\hline
\end{tabular}




\begin{tabular}{|c|c|c|c|}
\hline $\begin{array}{l}\text { Coscinodiscus concinnus } \\
\text { Cos. Granii } \\
\text { Dhtizosolenia alata forma indica }\end{array}$ & $\begin{array}{l}+ \\
+ \\
+\end{array}$ & $\begin{array}{l}+ \\
+ \\
+\end{array}$ & $\begin{array}{l}+ \\
+ \\
+\end{array}$ \\
\hline Dinoflagellates & & & \\
\hline Pyrophacns horologicum & + & + & + \\
\hline Ceratium cande!abrum & & + & + \\
\hline Cer. trichoceros & + & + & + \\
\hline Peridinium dsprossum & + & + & + \\
\hline
\end{tabular}

Table I. Number of species occurred at each station.

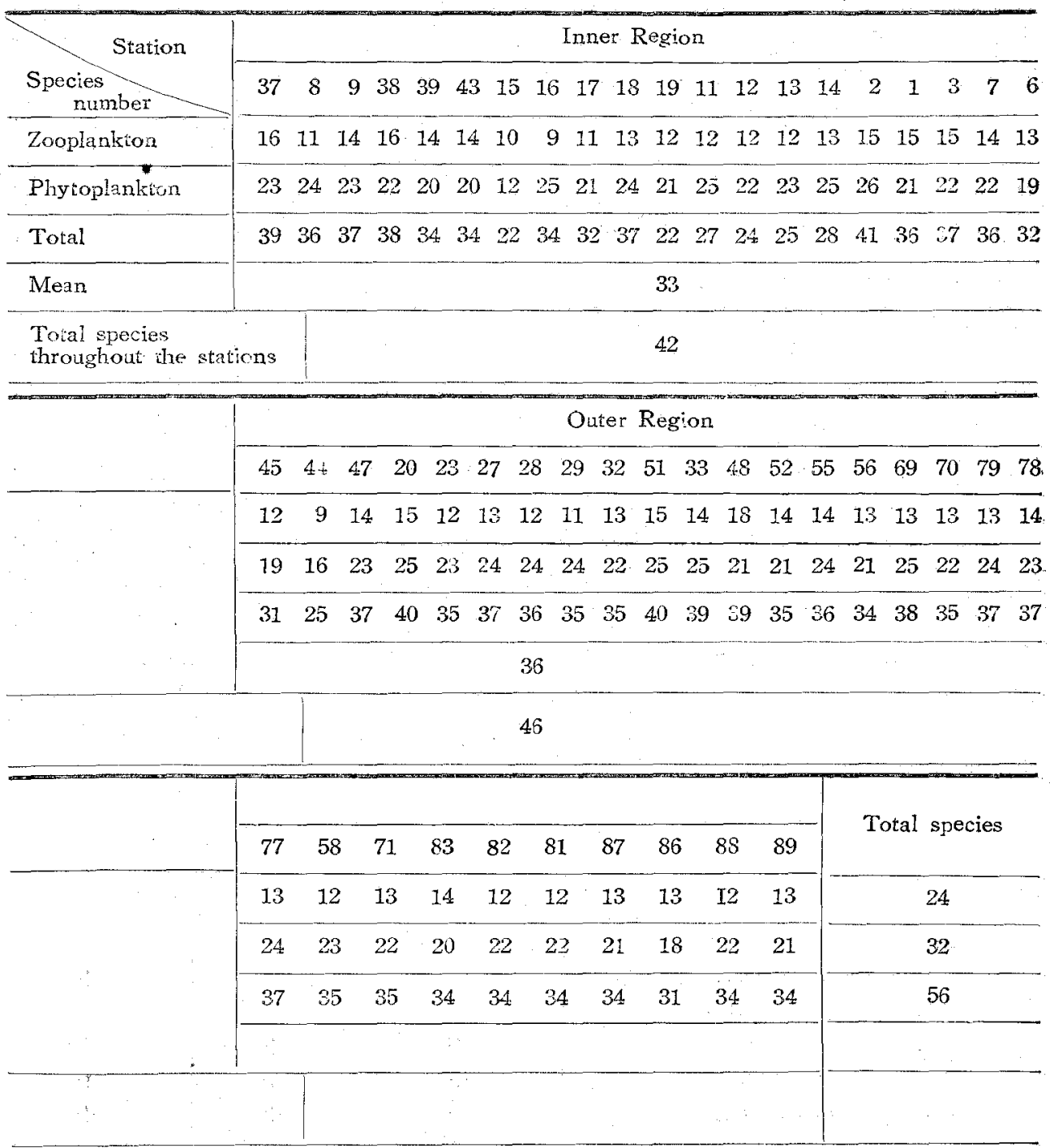


Number of species: Among 56 species of plankton found during the survey, 32 species consisted almost exclusively of pelagic phytoplankters. As shown in the preceding table, the number of species did not vary greatly according to stations, though a little larger in the outer region than in the inner.

\section{General Consideration on Regional Distribution}

From available data described above, it seems clear that the distribution of plankton in the bay varies widely from place to place, depending largely on the qualitative composition of the community, and it is directly influenced by the topographical and hydrological conditions. Furthermore in inshore waters of bays and inlets, the seasonal succession of planktons is more remarkable than elsewhere. In the following I will desire to make animals, which are locally dominant or characteristic and relatively unchangeable in abundance, as indi-

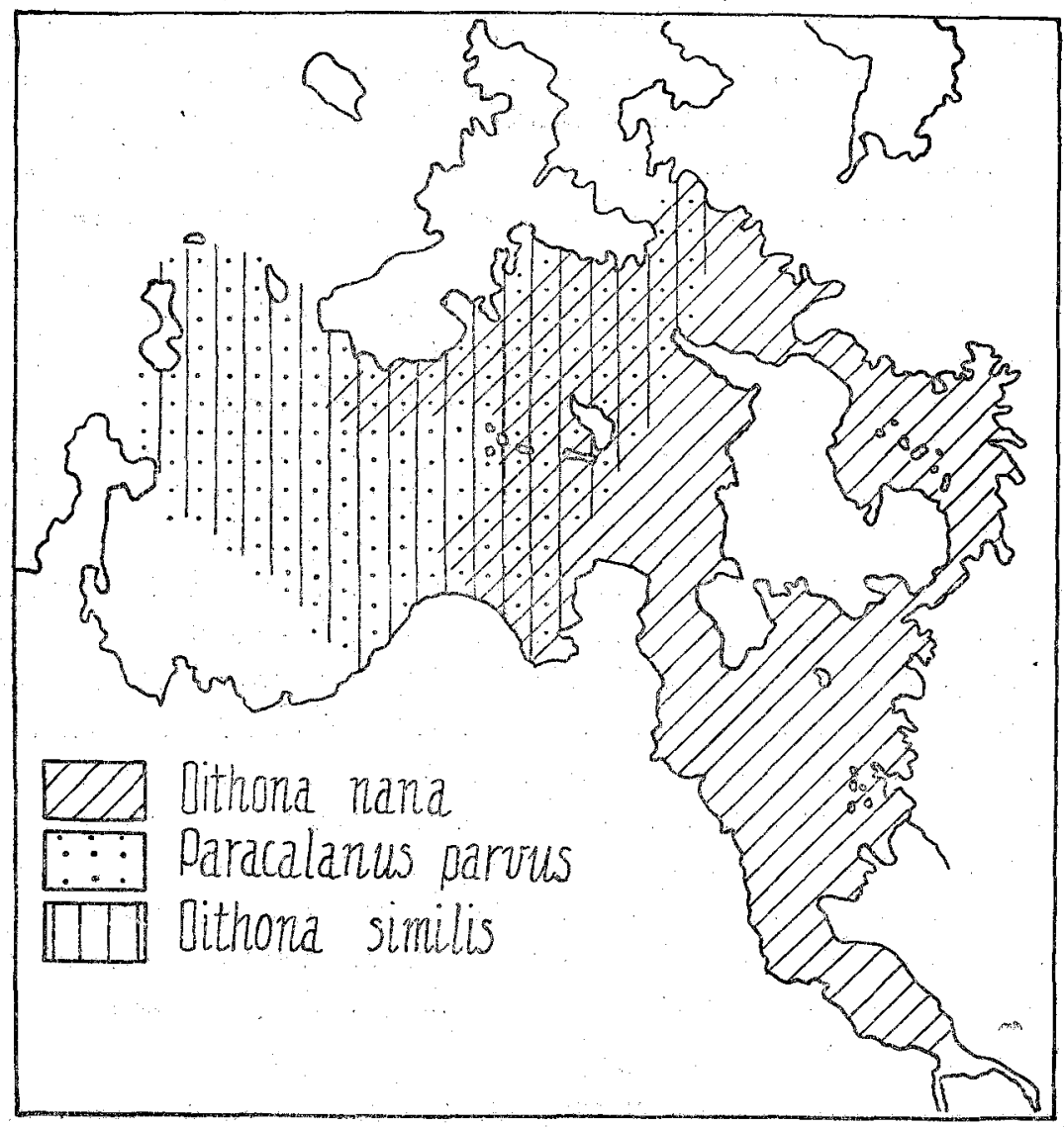

Fig. 8. Distribution of dominant copepods. 
cative of regional distribution. In this way the following three kinds of copepods may be recogizized as indicators of plankton distribution in Imari Bay: Oithona nana, Paracalamus parvu and Oithona similis (Fig. 8).

\section{Oilhonz nana area.}

The inner region and the easterin half of the outer region of the bay were widely occupied by the Oithona nana association. The de asity of population in the inner region was very large, up to 1600 per 10 liters. According to WiBorG (1940), this species is numerous in the innermost part of Oslo Fjord. About twothirds area of Imari Bay was dominated by Oithona nana. The association was characterized by the combination of large number of larval forms, especially copepod juveniles (chiefly nauplii and copepodids of Oithona nana) and diatoms, such as Skeletonema costatum, Nitzschia seriata and Thalas siothrix Frauenfeldii. It was also associated with Paracalanus parvus and Oithona similis in neighbouring area of the outer region, where they formed an intermixed area. Ceratium (i.e. C. fusus, C, inflexum, C. pennatum, etc.) was poor in occurrence in the inner region, but in considerable quantities outside of the island Hukusima. The animal constituents of this association were few in number, but their population was very large. Diatoms were also few both quantitatively and qualitatively, but dinoflagellates were relatively rich in species.

The water of this area was highly stagnant and colored yellowish brown with small transparency and low salinity in the surface layer, and of high values of phosphates and silicates, especially in the innermost part. This is mainly due to the pouring of river water from Imari-gawa at the head. Such environmental condition may be enough to supply rich nutrient organisms as good food for Oithona nana which is considered to be a detrituseater ( $\mathrm{W}_{\mathrm{iBORG}}$, 1940, p. 21). The low pH value and low saturation degree of dissolved oxygen observed in this area may be due in part to the poorness of phytoplankton in comparison with the unusual abundance of Oithona nana and other zooplankton. Besides, the influence of wind direction on the distribution of salinity may not be neglected. In summer the prevailing southerly winds are apt to flow out under topographical influences. The surface water of low salinity of the inner region flows to the outer region through both narrow channels east and west of Hukusima, and overlies widely on the more saline water of the bay intruding from the open sea. This is clearly deduced from the distribution of plankton, especially in reference to the population of Oithona nana.

\section{Oithona similis-Paracalanus parvus area.}

Most of the outer region of the bay, namely the northwestern entrance and the western half of the central part, was characterized by the dominance 
of two copepods Paracalanus parvus and Oithona similis, where the populations were $30-50$ and 30-40 per 10 liters, respectively. Next Microselella norvegica, Acartia clausi and diatoms such as Thalassiothrix and Chatoceros spp. were rather abundant, though much less than the former two. The others were common to both the areas, though occurring sparsely. They are: Euterpe acutifrons, Corycaeus crassiusculus, Noctiluca scinizllans, Codonellopsis morchella, Oikopleura dioca, Sagitia crassa forma naikaiensis, Podon sp., Evadne nordmanii, Penilia schmackeri, polychaete larvae, nauplii of copepods, and veligers of bivalves and snails. The number of species occurring in this area was small as in the above metioned inner region and the population density was smaller than that of the inner region. Of dinoflagellates which formed the main component of phytoplankton, many offshore species were found in the bay. The densest population was found in the southern part of the outer region, where is the most westward extension of the Oilhona nana area.

The water of this area was relatively stagnant and showed higher transparency and salinity, and lower water color than in the Oithona nana area. The high $\mathrm{pH}$ value (8.3) and high saturation degree of oxygen (about 100\%) were observed. The eastern half of this area is combined with the northerly widespread extension of Oithona nana area.

\section{Summary}

In short, the Imari Bay, so far as I surveyed, seems to be characterized by the extraordinary predominance of zooplankton, in contrast to other bays or inlets in Hokkaido hitherto surveyed (YAMAZI, 1950, 1951), where phytoplankton population greatly surpassed zooplankton.

The inner region of the bay was predominated by an inshore copepod, Oithona nana in an extraordinary dense association, and the outer region was characterized by the mixed associations of Oithona similis, Paracalanus parvus, Microsetella norvegica and Corycaevs crassiusculus, besides Oithona nana. The tendency of distribution was generally similar to that in the bays and inlets hitherto surveyed. The widespread distribution of Oithona nana extends further outwards to the eastern half of the outer region, though less than the dominant species there in occurrence.

This may be attributed partly to the effect of the southerly direction of prevailing winds in summer, and partly to the relatively stagnant condition of the bay water. It is, however, a question whether such condition is parmanent or temporary. To explain these facts, further detailed survey in other seasons is much desired. 


\section{REFERENCES}

WrBORG, K. F. 1940. The production of zooplankton in the Oslo Fjord in 1933-1931. Hvalr:dets Skrifter, Nr. 21.

YAMAZI, I. 1950. Plankton investigation in inlet waters along the coast of Japan. I. Introductory notes and the plankton of Akkeshi Bay, Hanasaki Inlet and Nemuro Harbour. Publ. Seto Mar. Biol. Lab, vol 1, no. 3.

1951. Idem. II. The plankton of Hakodate Harbour and Yoichi Inlet in Hokkaido. Ibid., vol. 1, no. 4 . 